\title{
Discussion on Problem and its Solving Strategy of China's Education Based on Comparison with American Education
}

\author{
Zhiquan zhang, Ying shen \\ Educational Faculty of Nantong University Jiangsu Nantong 226019
}

\begin{abstract}
It is true that American high education is much better than china's. but to basic education, some say America's is better because of American children do not need to do too much writing homework and have much time to develop their comprehensive abilities both at home and school. But some say china's basic education is much better because Chinese student can learn much more subject knowledge than America's especially on math, physics and chemistry. So some people say why quarrel too much on which is better, China should learn the better aspects of American basic and high education on the basis of keeping its good aspects and then Chinese education can be better and be improved. But after a better understanding of American education, we know it is impossible for Chinese education to do so on some aspects just because china's social system. In the social system, Chinese government has to pay much attention on fair, justice and that's make education efficiency on some aspects almost impossible.
\end{abstract}

Keyword: high education; basic education; talent selection; social system

In the world, there are a lot of things need to be compared. After comparison, we keep things' good aspects and improve or get rid of its shortcoming. It is no doubt that education is an important thing that needs us to compare. As the world's two important countries, china and America's education has its distinct characteristic. Making a comparison between them has great significance.

\section{BASIC EDUCATION COMPARISON BETWEEN TWO COUNTRIES}

On basic education, some say America's basic education is good, because it is good for child's health and development. In basic education, American child need not to go to school so early, they get to school at eight o' clock or eight thirty in the morning, that can ensure student to have a good sleep. But in china, student must get to school half an hour or an hour earlier than in America. That makes lot of student not sleep well. And also in America, school is over at three or half past three in the afternoon, So student do not need to stay at school so long, They have lot of time to play. But in china, that's a little different, primary school student have to stay in school until half past four Pm and middle school student have to stay in school until twenty past five. In senior middle school, student will have to go to school at 6:00 Am and leave school at 6:00pm. It is true that Chinese student stay in school much longer than America's. But this is not the key of problem. The key of the problem is what the students do at school. What students do at school in China. The most important thing that Chinese students do at school is memorizing, reading, understanding knowledge in text book and listen attentively to what teacher teach in class. Although, schools have set one or two PE, Art, Music classes every week for students to develop their hobbies and excise their skills. But in high grade in primary school and in middle school these classes are often occupied by math, Chinese or English teacher. So what Chinese students do at school is mainly learning knowledge in text book. May be learning much knowledge is not a bad thing for student's development, but sacrifice student health, hobbies and necessary rest time is not good thing for Chinese education to do. That can be seen in teacher's teaching styles, class should be a place for increasing student knowledge, learning, thinking and speaking abilities, the class should be dynamic and gives student more chance to think, speak and communicate with each other. But in most cases, class becomes a place for teacher to develop themselves but not student. When some teachers get into class, the only thing they do is to ask student to be quiet and can't speak without his(her) permission. Students have to sit quietly just listen to what the teacher says. Even in recess time, there are still some teachers patrolling in schoolyard or corridor to prohibit students' 
strenuous exercises. One class after one class and one day after one day, that leads to a very horrible result, that is with the grade raising, student tend to keep silent and do not like to discuss and speak and also because of static life of sitting in classroom so long, many Chinese students' health is very bad, Obesity, weak, Humpback, high myopia ${ }^{1}$, Psychological anxiety become common problems of Chinese students. While in America or other country, student in primary school and middle school have more time to play, student can lead a relative happy life and increase their interests in their leisure time. That helps them get rich life experience and feeling.

\section{Analysis on Reasons of the Problems}

Do Chinese governments know the shortcoming of its basic education? Of course they know clearly. Why they don't improve it? There are two reasons.

One is that the central government doesn't want to change it. The central government knows it is good for boys to have strong body, they can arrange student to exercise Chinese boxing, acrobatics, and other fighting skills. But they do not want to do so. Because they realize that the youth who is weak is easy to be ruled. If all the youth who study in school are strong enough to fight. Some of them will make some disturbance in society in future. It will give them some difficulty to rule them and control society. That's a very selfish idea.

The second is that they can't change it. Why they can't change it? Because there are two kinds of resistances, one is from fairness, another is the obstacle from vested interests.

The obstacle from fairness is the biggest. Why is it so? Because of china's social system, China is socialist public ownership. All top universities are public university, top university successively include " 985 " university ${ }^{2}$, "211" university ${ }^{3}$ and key university of every province. Since all top universities are public university, so all the students in china have right to study in these universities. Those who can study in top university is not only the pride of their parents, neighbors and relatives, but also easy to find a good job. Who can get in top university becomes a big problem in china. To ensure fairness, china has to use College entrance examination scores to decide who can get into the best university. The higher the score is, the better university student can get into. Every university has an Admission score, if the student's score reach the score line, any university can't reject them if they select the university. In order to get into top university to study, all Chinese student have to study hard from primary school to senior middle school, although which primary school and junior middle they will get in is decided by which area they live in not by their exam score, but which senior middle school they can get in is truly decided by their final test score in grade 9. Only these who can get in key or top senior middle school (high school) to study may get into top university. So from primary school to senior middle school, all students will put all their heart into studying text book in order to be top student in every step and also teacher will try their best to make student study knowledge in text book well while students' development in other aspects are neglected. Although china has seen the shortcoming in cultivating and selecting talents and have made some reform, for example, Key universities autonomous enrollment and The principal recommendation system, but because of Triggering enrollment corruption and problem of educational equity, these reform can't continue. But in America, the situation is not the case, most top universities are private university, such as Harvard university, Princeton university and so on. Student being enrolled in these universities come from all over the world, these universities can select student according to their own standard not just see student's SAT test scores and AP test scores. ${ }^{1}$ They also select students according to students' grades in high school and usual performance, for example, to see what kind of activity or organization

\footnotetext{
${ }^{1}$ According to the survey of China's primary health care fund in 2014 , China 's children's myopia rate is $30 \%$ in primary school, $60 \%$ in junior middle school , $85 \%$ in senior middle school and $90 \%$ in college.

2“985" university are universities that chairman Jiang Ze-Min declared on the occasion of Centennial ceremony of Tsinghua university on 4th may 1998 that China will develop some famous top universities in the world. China will support these universities on policy and fund. From now on, there are 37 universities are listed in "985" university.They are the toppest university in china.

3“211" university is also called "211"project.That's put forward by Chinese government to develop 100 top universities and key subjects in 21 century. In 1995, this project is approved by the State Council and is started on that day.
} 
student have ever taken part in and whether they are excellent enough in all kinds of activities or serve as leader of an organization and so on. So if the student is very excellent in usual study and all kinds of activities, many universities know them. If one student selects one or two universities, university will decide whether recruit him according to the information they know and the standard of its university. Student selecting Criteria in American university effect American basic education. Student in America will try to be excellent according to standard of these universities. From the above comparison, we can see that American university need not consider fairness too much. But China's university must pay enough attention on fairness, selecting students according to their College entrance examination scores may be the fairest way.

To the obstacle from vested interests, the vested interest mainly refer to the parents in china's two biggest cities-BeiJing (capital of china) and ShangHai(centre and super city in china). Many top universities are in the two cities. For example, There are 34 Provincial Administrative regions and 37 "985" universities in china, eight "985" universities are in BeiJing and 4 in ShangHai. Key university's Localization in enrolling students is very serious, in 2014,Peking University (BeiJing)enrolled 27\% of the total in Beijing, Fudan University(Shanghai) enrolled $40 \%$ of the total in Shanghai, Zhejiang University enrolled $70 \%$ of the total in Zhejiang province. ${ }^{2}$ Students in those regions with many top universities are much easier to be enrolled by top universities. Many parents in these regions especially in Shanghai and Beijing are mainly these with wealth and power. They do not want to reform College entrance examination a lot, because it is easier for their children to get into top university to study. Basic education in the two cities can have flexible change.

\section{How to Solve Problem in Chinese Education Through Cooperation with AMERICA}

It is time for Chinese education to reform. Before 1998 in china, most of university and college do not recruit too much students. There are less universities in which the total numbers of students exceed 10 thousand. Almost all college students can find a satisfied job after their graduation. But from 1998, the central government decided to expand the enrollment scale of colleges or Universities. From then on, there is a sharp increase in the number of college students. Most of university's student numbers exceed twenty thousand, some even exceeds fifty thousand. For example, Tsinghua university enrolled 11054 students in 2015.include 4754 postgraduates and 2733 doctors. The overall students exceed 46200 . The overall students in ZheJiang university reached 47339 . While in Ji Lin university, the overall students exceed 69587.

In this situation, a serious problem comes, that is it is difficult for student to find a good job after their graduation. Some have to do the job with very low salary, much lower than those who haven't studied in college. So some student doubt why they study so hard just for getting into university in which they can't learn skills that can help them find good job. In this case, china's education must reform.

It is easy for American basic and high education to reform because many of them are private. They can reform according to their own willingness. But in china, almost all schools and university are controlled by government and affected by politics. They dare not change $30 \%$ content that student must learn such Political ,Ideological and Moral courses. So if china wants to have repaid progress in education. It needs not only carrying out education reform on the system of Universities' selecting talents and talent cultivating mode in various types in school, but also relax the control of running school and education, permitting different countries all over the world to set up primary school, middle school and university in China. So student in China can select the school or the kind of education they like if their families can afford them to do so. Thus it can create a competitive atmosphere between public school and private school. That will push public school to carry out real reform to improve its education efficiency.

Also, In American, there are much more top universities than in China. But these top universities do not enroll so many students as in China. For example, this year (2016), Harward University enrolled 918 student from $6173{ }^{3}$ applicants. Princeton enrolled 1894 students from 29,303 applicants, Yale University enrolled 1,972 students from 31,455 applicants. The overall students of any university in America include postgraduate and doctors are no more than twenty thousand. 
Since china has so many students need to study in university especially in top universities, it is necessary for two countries to cooperate on education, especially on high education. China should encourage American university to open branch campus in china. Thus china's education can be improved through the cooperation and communication with American Education.

This article is the achievement of the National Science Education 1025 planning key project: excellent teacher training effectiveness "value-added" evaluation research, approval number: DIA150318

\section{REFERENCES}

[1] Shengyao Feng. How to understand American college entrance examination system. Education measurement and evaluation,2011,2.

[2] Yang LI.The fighting behind the university enrolling number allocation. China News Weekly, 2006,3,27.

[3] Study aboard circle in Hubei.Latest /2016 American college admission data summary. http://sanwen8.cn/p/ 1a6Dq8p.html, 2016-07-12.

\section{AUTHORS' BIOGRAPHY}

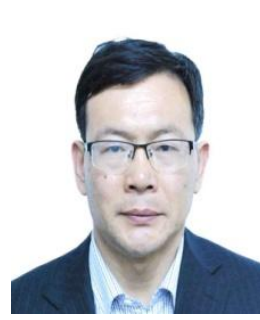

ZhiQuan Zhang (1972-) , male, born in YanZhou county Shandong province, China. vice professor in educational science faculty of Nantong university, post graduate tutor ,post doctor, visiting scholar of Duequsne University. Research on educational principle theory.

Ying Shen (1991-) female, born in Tongzhou city, postgraduate, studying educational principle theory in educational faculty in Nantong university. 